\title{
Synthesis and Biodegradability of New Polyesteramides Containing Peptide Linkages
}

\author{
Yujiang FAN, Masami KoBAYASHI, and Hideo KISE ${ }^{\dagger}$ \\ Institute of Materials Science, University of Tsukuba, Tsukuba, Ibaraki 305-8573, Japan
}

(Received January 11, 2000; Accepted June 20, 2000)

\begin{abstract}
Monomers having amino acid residues at the both ends were synthesized from amino acids, adipoyl chloride, and 1,4-butanediol. Polyesteramides containing peptide linkages (Phe-Phe, Phe-Leu, Phe-Val, and Phe-Ala) were synthesized from these monomers by using 1-ethyl-3-(3-dimethylaminopropyl) carbodiimide hydrochloride as the coupling agent. Polymers with moderate molecular weight (5600-7700) were obtained. These polymers were soluble in organic acids and polar aprotic solvents such as dimethyl sulfoxide (DMSO) and $N, N$-dimethyl formamide (DMF), as well as in chloroform. The results of biodegradation studies indicated that all of these polyesteramides were hydrolyzed by enzymes, such as $\alpha$-chymotrypsin, subtilisin Carlsberg, and lipase. The rate of degradation depended strongly on the nature of amino acid residues in the polymer chains reflecting the enzyme specificity. The polymers obtained are anticipated to find agricultural or biomedical applications.

KEY WORDS Polyesteramide / $\alpha$-Amino Acid / Peptide Linkage / Biodegradability / Enzymatic Hydrolysis /
\end{abstract}

Several aliphatic polyesters exhibit excellent biodegradability, and they are now extensively employed for agricultural, biomedical, as well as pharmaceutical and environment-related applications. ${ }^{1}$ However, low thermal, mechanical, and processing performances greatly restrict the practical use of these materials. ${ }^{2,3}$ Improvement of the mechanical properties can be achieved by introduction of amide linkages in the main chains. For example, $\varepsilon$-caprolactam, adipic acid, and 1,6-hexanediamine have been used as monomers for the synthesis of polyesteramides. ${ }^{4-6}$ In general, however, these polymers exhibit low biodegradability, because the amide linkages are not sensitive to the attack by enzymes and microbes. ${ }^{5,6}$

Amino acids are constituents of proteins, and polymers synthesized from amino acids are expected to exhibit biodegradability. ${ }^{7-10}$ Polyesteramides containing amino acids, such as phenylalanine, leucine, alanine, and glycine, have been synthesized and they were found to be degraded by enzymes. ${ }^{11-14}$ For example, a series of polyesteramides were synthesized starting from amino acids, adipic acid, and 1,2-ethanediol. ${ }^{11,12}$ The polymers could be degraded by $\alpha$-chymotrypsin $(\alpha$-CT) and elastase, except for the polymer containing glycine residues. Also, Arabuli and coworkers ${ }^{13}$ reported the synthesis of polyesteramides having phenylalanine residues and showed that these polymers were degraded by $\alpha$-CT. Paredes and co-workers ${ }^{14}$ synthesized glycinecontaining polyesteramides that were degradable by papain.

Many serine proteases, such as $\alpha$-CT and subtilisins, ${ }^{15}$ are well known as catalysts for hydrolysis of peptides or proteins, especially for those containing aromatic amino acid residues as carboxyl components ( $\mathrm{P}_{1}$ specificity). In the present work, a series of polyesteramides were synthesized which contained dipeptide groups composed of phenylalanine and several other amino acids in the main chain. The biodegradability of these polymers was

\footnotetext{
${ }^{\dagger}$ To whom correspondence should be addressed.
}

estimated from the enzymatic hydrolysis by proteases and a lipase.

\section{EXPERIMENTAL}

\section{Materials}

L-Phenylalanine $\left([\alpha]_{\mathrm{D}}-32.4\right)$, L-leucine $\left([\alpha]_{\mathrm{D}}-11.0\right)$, L-valine $\left([\alpha]_{D}+5.63\right), \quad$ L-alanine $\left([\alpha]_{D}+1.8\right), \quad 1,4-$ butandiol, and $p$-toluenesulfonic acid monohydrate were obtained from Wako Pure Chem. Ind., Ltd., and they were used as received. Adipoyl chloride was purchased from Tokyo Kasei Kogyo Co., Ltd., and it was purified by distillation. 1-Ethyl-3-(3-dimethylaminopropyl)carbodiimide hydrochloride $(\mathrm{EDC} \cdot \mathrm{HCl})$ was also a product of Tokyo Kasei, and it was used without further purification. Triethylamine was dried over calcium hydride and distilled. Except for nitrobenzene, all the solvents used were distilled and stored over $4 \AA$ molecular sieves.

$\alpha$-Chymotrypsin ( $\alpha$-CT, 54 units/mg solid for hydrolysis of $N$-benzoyltyrosine ethyl ester, EC 3.4.21.1) from bovine pancreas, subtilisin Carlsberg (STC, 12 units/mg solid for hydrolysis of casein, EC 3.4.21.62) from Bacillus licheniformis, subtilisin BPN' (STB, 8.1 units/mg solid for hydrolysis of casein, Nagarse, EC 3.4.21.62) and lipase from Candida cylindracea (LCC, 690 units/mg solid for hydrolysis of triglyceride, EC 3.1.1.3) were purchased from Sigma Chem. Co. and were used without further purification.

\section{Measurements}

Infrared absorption spectra (IR) were recorded with a JASCO FT/IR-300 Fourier transform infrared spectrometer on $\mathrm{KBr}$ pellets. Nuclear magnetic resonance (NMR) spectra were recorded using a Bruker AM-500 NMR spectrometer operating at 500 and $125 \mathrm{MHz}$ for ${ }^{1} \mathrm{H}$ and ${ }^{13} \mathrm{C}$ nuclear magnetic reasonace (NMR) investigations, respectively, using DMSO- $d_{6}$ as a solvent and tetramethylsilane (TMS) as an internal standard. Specific optical rotation $[\alpha]_{D}$ was measured with a JASCO DIP. 140 digital polarimeter for amino acids and monomers (I 
and II) in water and $N, N$-dimethy lacetamide (DMAc), respectively. Melting points were measured with a Yanako micromelting point apparatus. Gel permeation chromatography (GPC) analyses were conducted for polymers in $\mathrm{N}, \mathrm{N}$-dimethyl formamide (DMF) containing $1 \%(\mathrm{w} / \mathrm{v}) \mathrm{LiBr}$ (flow rate $1.0 \mathrm{~mL} \mathrm{~min}^{-1}$ ) using a JASCO GPC-9000 system equipped with an RI detector and a Tosoh $\alpha-3000$ polystyrene column. Polyethylene glycol from Polymer Laboratory was used as a standard polymer for calibration. Total organic carbon (TOC) analyses were performed with a Shimadzu TOC-500 total organic carbon analyzer which was calibrated using potassium hydrogen phthalate. TOC values due to polymer degradation were calculated by subtracting the TOC due to enzyme $(58 \mathrm{ppm})$ from the TOC of solutions of degradation reactions.

\section{Synthesis of Monomers}

Di(phenylalanine)adipamide $(\boldsymbol{I})$. To a mixture of Lphenylalanine $(4.13 \mathrm{~g}, 25 \mathrm{mmol})$ and $60 \mathrm{~mL}$ aqueous 1,4-dioxane $(1: 1 \mathrm{v} / \mathrm{v})$ cooled to $0^{\circ} \mathrm{C}, 25 \mathrm{~mL}$ aqueous $1 \mathrm{~N} \mathrm{NaOH}$ solution was added gradually with stirring. To this solution, a solution of adipoyl chloride $(1.83 \mathrm{~g}$, $10 \mathrm{mmol}$ ) in $10 \mathrm{~mL} \mathrm{1,4-dioxane} \mathrm{and} 20 \mathrm{~mL} 1 \mathrm{~N}$ aqueous $\mathrm{NaOH}$ solution were added in drops from two funnels simultaneously over about $1 \mathrm{~h}$. The solution was then stirred for $1 \mathrm{~h}$ at $0^{\circ} \mathrm{C}$ and $1 \mathrm{~h}$ at room temperature. 1,4Dioxane was evaporated under reduced pressure, and the remaining aqueous solution was washed twice with $20 \mathrm{~mL}$ ethyl acetate. Then, the aqueous solution was acidified with $36 \%$ hydrochloric acid to $\mathrm{pH} 3$, and the white precipitates were extracted 4 times by $50 \mathrm{~mL}$ ethyl acetate. Organic phases were combined, dried with $\mathrm{Na}_{2} \mathrm{SO}_{4}$, and evaporated under vacuum to dry. The residue was recrystallized twice from water to obtain $2.4 \mathrm{~g}$ $(55 \%)$ of the product: melting point $79-82^{\circ} \mathrm{C},[\alpha]_{\mathrm{D}}-9^{\circ}$ $\left(c=2\right.$, DMAc, $\left.25^{\circ} \mathrm{C}\right) . \operatorname{IR}\left(\mathrm{cm}^{-1}\right): 3517(-\mathrm{OH}), 3307(-\mathrm{NH}-)$, $1727(-\mathrm{C}(\mathrm{O}) \mathrm{OH}), 1639$ (amide $\mathrm{I}), 1535$ (amide $\mathrm{II}$ ). ${ }^{1} \mathrm{H} \mathrm{NMR}(\mathrm{ppm}): \delta=1.46\left(2 \mathrm{H},-\mathrm{COCH}_{2} \mathrm{CH}_{2}-\right), 2.12(2 \mathrm{H}$, $\left.-\mathrm{COCH}_{2} \mathrm{CH}_{2}-\right), 2.96-3.15\left(2 \mathrm{H}, \mathrm{PhCH}_{2}-\right), 4.67(1 \mathrm{H}$, $\left.-\mathrm{COCH}\left(\mathrm{CH}_{2} \mathrm{Ph}\right) \mathrm{NH}^{-}\right), 7.31-7.48(5 \mathrm{H},-\mathrm{Ph}), 8.17(1 \mathrm{H}$, -N $\left.H^{-}\right) .{ }^{13} \mathrm{C} \mathrm{NMR}(\mathrm{ppm}): \delta=24.74,34.92,36.94,53.43$, $126.51,128.28,129.20,137.64,172.18,173.32$.

\section{p-Toluenesulfonic Acid Salt of Bis(L-phenylalanine)-1,4- butane Diester (II a)}

L-Phenylalanine $(8.92 \mathrm{~g}, 54 \mathrm{mmol})$, 1,4-butanediol $(2.25 \mathrm{~g}, 25 \mathrm{mmol})$ and $p$-toluenesulfonic acid monohydrate $(12.28 \mathrm{~g}, 54 \mathrm{mmol})$ in $70 \mathrm{~mL}$ nitrobenzene/benzene $(1: 1 \mathrm{v} / \mathrm{v})$ were heated to refulx with stirring. Heating was continued until no more water, which was separated by a Dean-Stark apparatus, was distilled $(3-4 \mathrm{~h})$. The mixture was then cooled to room temperature, and $50 \mathrm{~mL}$ benzene was added. The white precipitates were separated by filtration, washed with benzene $(50 \mathrm{~mL}$ $\times 3$ ), and dried under vacuum. The product was recrystallized twice from water to obtain $13.27 \mathrm{~g}(74 \%)$ of IIa: melting point $234.5-236.5^{\circ} \mathrm{C} ;[\alpha]_{\mathrm{D}}+25(c=2$, DMAc, $\left.25^{\circ} \mathrm{C}\right)$; IR $\left(\mathrm{cm}^{-1}\right) 1737(-\mathrm{C}(\mathrm{O})-), 1200(-\mathrm{O}-)$; ${ }^{1} \mathrm{H}$ NMR (ppm) $\delta=1.31 \quad\left(2 \mathrm{H}, \quad-\mathrm{OCH}_{2} \mathrm{CH}_{2}-\right), \quad 2.29 \quad(3 \mathrm{H}$, $\left.\mathrm{CH}_{3} \mathrm{PhSO}_{3}{ }^{-}\right), \quad 3.02-3.15\left(2 \mathrm{H}, \mathrm{PhCH}_{2}{ }^{-}\right), 3.96(2 \mathrm{H}$, $\left.-\mathrm{OCH}_{2} \mathrm{CH}_{2}-\right), 4.28\left(1 \mathrm{H},-\mathrm{COCH}\left(\mathrm{CH}_{2} \mathrm{Ph}\right) \mathrm{NH}-\right), 7.12-7.52$ $\left(9 \mathrm{H}, \mathrm{Ph}^{-}, \mathrm{CH}_{3} \mathrm{Ph} h^{-}\right), 8.46\left(3 \mathrm{H},-\mathrm{NH}_{3}{ }^{+}\right) ;{ }^{13} \mathrm{C} \mathrm{NMR}(\mathrm{ppm})$ $\delta=20.67,24.00,36.04,53.15,64.81,125.40,127.15$, $128.04,128.49,129.21,134.54,137.62,145.17,168.88$.

\section{p-Toluenesulfonic Acid Salt of Bis(L-leucine)-1,4-butane} Diester (IIb)

Compound IIb was prepared by a similar method to that for IIa from L-leucine $(7.08 \mathrm{~g}, 54 \mathrm{mmol}), 1,4-$ butanediol ( $2.25 \mathrm{~g}, 25 \mathrm{mmol})$, and $p$-toluenesulfonic acid monohydrate $(10.28 \mathrm{~g}, 54 \mathrm{mmol})$. The product was recrystallized twice from water to obtain $16.52 \mathrm{~g}(57 \%)$ of IIb: melting point $242-244^{\circ} \mathrm{C}$; $[\alpha]_{\mathrm{D}}+7.2(c=2$, DMAc, $\left.25^{\circ} \mathrm{C}\right)$; IR $\left(\mathrm{cm}^{-1}\right) 1745(-\mathrm{C}(\mathrm{O})-), 1214(-\mathrm{O}-)$; ${ }^{1} \mathrm{H}$ NMR $(\mathrm{ppm}) \delta=0.93-0.98 \quad\left(6 \mathrm{H},-\mathrm{CH}\left(\mathrm{CH}_{3}\right)_{2}\right), \quad 1.67 \quad(2 \mathrm{H}$, $\left.-\mathrm{OCH}_{2} \mathrm{CH}_{2}-\right), \quad 1.84\left(1 \mathrm{H},-{ }^{-} \mathrm{CH}\left(\mathrm{CH}_{3}\right)_{2}\right), \quad 1.94 \quad(2 \mathrm{H}$, $\left.{ }^{-} \mathrm{CH}_{2} \mathrm{CH}\left(\mathrm{CH}_{3}\right)_{2}\right), 2.31\left(3 \mathrm{H}, \mathrm{CH}_{3} \mathrm{PhSO}_{3}{ }^{-}\right), 3.90 \quad(1 \mathrm{H}$, $\left.-\mathrm{COCH}\left(\mathrm{CH}_{2} \mathrm{CH}\left(\mathrm{CH}_{3}\right)_{2}\right) \mathrm{NH}^{-}\right), 4.21\left(2 \mathrm{H},-\mathrm{OCH}_{2} \mathrm{CH}_{2}-\right)$, $7.14(2 \mathrm{H},-\mathrm{Ph}-), 7.49(2 \mathrm{H},-\mathrm{Ph}-), 8.32\left(3 \mathrm{H},-\mathrm{NH}_{3}{ }^{+}\right)$; ${ }^{13} \mathrm{C} \mathrm{NMR}(\mathrm{ppm}) \quad \delta=17.79,18.27,20.84,22.70,24.85$, 27.97, 57.41, 65.15, 125.60, 128.17, 138.02, 139.39, 171.90 .

\section{p-Toluenesulfonic Acid Salt of Bis(L-valine)-1,4-butane Diester (IIc)}

The compound IIc was prepared by a similar method to that for IIa from L-valine $(6.33 \mathrm{~g}, 54 \mathrm{mmol}), 1,4$ butandiol $(2.25 \mathrm{~g}, 25 \mathrm{mmol})$, and $p$-toluenesulfonic acid monohydrate $(10.28 \mathrm{~g}, 54 \mathrm{mmol})$. The product was recrystallized twice from ethanol to obtain $5.50 \mathrm{~g}(34 \%)$ of II c: melting point $238-241^{\circ} \mathrm{C} ;[\alpha]_{\mathrm{D}}+10.2(c=2$, DMAc, $\left.25^{\circ} \mathrm{C}\right)$; IR $\left(\mathrm{cm}^{-1}\right) 1735(-\mathrm{C}(\mathrm{O})-), 1199\left(-\mathrm{O}^{-}\right)$; ${ }^{1} \mathrm{H}$ NMR $(\mathrm{ppm}) \quad \delta=0.93-1.02 \quad\left(6 \mathrm{H},-\mathrm{CH}\left(\mathrm{CH}_{3}\right)_{2}\right), 1.69 \quad(2 \mathrm{H}$, $\left.-\mathrm{OCH}_{2} \mathrm{CH}_{2}{ }^{-}\right), \quad 2.15 \quad\left(1 \mathrm{H}, \quad-\mathrm{CH}\left(\mathrm{CH}_{3}\right)_{2}\right), \quad 2.29 \quad(3 \mathrm{H}$, $\left.\mathrm{CH}_{3} \mathrm{PhSO}_{3}{ }^{-}\right), \quad 3.89\left(1 \mathrm{H}, \quad-\mathrm{COCH}\left(\mathrm{CH}\left(\mathrm{CH}_{3}\right)_{2}\right) \mathrm{NH}-\right)$, 4.17-4.21 (2H, $\left.-\mathrm{OCH}_{2} \mathrm{CH}_{2}-\right), 7.12(2 \mathrm{H},-P h-), 7.48(2 \mathrm{H}$, $\left.-\mathrm{Ph}^{-}\right), 8.32\left(3 \mathrm{H},-\mathrm{N} \mathrm{H}_{3}{ }^{+}\right) ;{ }^{13} \mathrm{C} \mathrm{NMR}(\mathrm{ppm}) \delta=17.56$, $18.32,20.85,24.63,29.42,57.40,65.16,125.56,128.18$, $137.92,145.41,171.88$.

\section{p-Toluenesulfonic Acid Salt of Bis(L-alanine)-1,4-butane Diester (IId)}

The compound IId was prepared by a similar method to that for IIa from L-alanine $(4.81 \mathrm{~g}, 54 \mathrm{mmol}), 1,4$ butandiol $(2.25 \mathrm{~g}, 25 \mathrm{mmol})$, and $p$-toluenesulfonic acid monohydrate $(10.28 \mathrm{~g}, 54 \mathrm{mmol})$. The product was recrystallized from ethanol to obtain $5.71 \mathrm{~g}(40 \%)$ of IId: melting point $189-192^{\circ} \mathrm{C} ;[\alpha]_{\mathrm{D}}+3.7\left(c=2\right.$, DMAc, $\left.25^{\circ} \mathrm{C}\right)$; IR $\left(\mathrm{cm}^{-1}\right) 1740(-\mathrm{C}(\mathrm{O})-), 1205(-\mathrm{O}-) ;{ }^{1} \mathrm{H}$ NMR $(\mathrm{ppm}) \delta=$ $1.37\left(3 \mathrm{H},-\mathrm{CH}_{3}\right), 1.63\left(2 \mathrm{H},-\mathrm{OCH}_{2} \mathrm{CH}_{2}-\right), 2.29(3 \mathrm{H}$, $\left.\mathrm{CH}_{3} \mathrm{PhSO}_{3}{ }^{-}\right), 4.08\left(1 \mathrm{H},-\mathrm{COCH}\left(\mathrm{CH}_{3}\right) \mathrm{NH}-\right), 4.16(2 \mathrm{H}$, $\left.-\mathrm{OCH}_{2} \mathrm{CH}_{2}-\right), 7.12(2 \mathrm{H},-\mathrm{Ph}-), 7.45(2 \mathrm{H},-\mathrm{Ph}-), 8.31$ $\left(3 \mathrm{H},-\mathrm{NH}_{3}{ }^{+}\right) ;{ }^{13} \mathrm{C} \mathrm{NMR}(\mathrm{ppm}) \delta=15.79,20.88,24.49$, $46.03,65.21,125.57,128.21,137.96,139.42,170.02$.

\section{Polymerization}

Monomers I ( $1 \mathrm{mmol})$ and II ( $1 \mathrm{mmol}$ ) were suspended in $2 \mathrm{~mL} \mathrm{DMF}$ and the mixture was cooled to $0^{\circ} \mathrm{C}$. EDC. $\mathrm{HCl}$ (460 mg, $2.4 \mathrm{mmol}$ ) was added to the mixture with stirring. The mixture was stirred for $1 \mathrm{~h}$ and then triethylamine $(0.306 \mathrm{~mL}, 2.2 \mathrm{mmol})$ was added. Then, the mixture was stirred for $2 \mathrm{~h}$ at $0^{\circ} \mathrm{C}$ and $8 \mathrm{~h}$ at room temperature. The obtained viscose solution was poured into $100 \mathrm{~mL} 0.1 \mathrm{M}$ aqueous $\mathrm{HCl}$ solution. The precipitates were filtered, washed with water, ethanol, water, and fi- 
<smiles>NC(Cc1ccccc1)C(=O)O</smiles>

Scheme 1.<smiles>[R]C(N)C(=O)O</smiles>
$\underset{\mathrm{TosOH} \mathrm{H}}{\stackrel{\text { Nitrobenzene, Benzene }}{\longrightarrow}}$

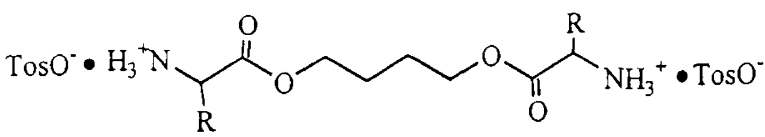

(II) IIa: $\mathrm{R}=-\mathrm{CH}_{2} \mathrm{Ph}$ IIb: $\mathrm{R}=-\mathrm{CH}_{2} \mathrm{CH}\left(\mathrm{CH}_{3}\right)_{2}$ IIc: $\mathrm{R}=-\mathrm{CH}\left(\mathrm{CH}_{3}\right)_{2}$ IId: $\mathrm{R}=-\mathrm{CH}_{3}$

Scheme 2.

nally dried under vacuum.

\section{Enzymatic Hydrolysis}

Emzymatic degradation of the polymers was carried out in borate buffer at $30^{\circ} \mathrm{C}$. A powdery polymer $(20 \mathrm{mg})$ was added to $10 \mathrm{~mL}$ borate buffer $(0.1 \mathrm{M}, \mathrm{pH} 8)$ containing $1 \mathrm{mg}$ enzyme. The mixture was incubated at $30^{\circ} \mathrm{C}$ with shaking. After a specified period of time, $1 \mathrm{~mL}$ of the solution was taken and filtered through a poly(tetrafluoroethylene) membrane filter with $0.5 \mu \mathrm{m}$ pore diameter. The degradability of the polymers was estimated by measuring TOC of the filtrate.

\section{RESULTS AND DISCUSSION}

\section{Synthesis of Monomers}

Di(phenylalanine)adipamide (monomer I) was synthesized from L-phenylalanine and adipoyl chloride under Schotten-Baumann condition as shown in Scheme 1. It is known that, under basic conditions, $\alpha$-amino acids undergo racemization. Therefore, the $\mathrm{pH}$ of the reaction solution was carefully kept at around 7 by controlling the addition of the solutions of $\mathrm{NaOH}$ and adipoyl chloride in order to avoid racemization of L-phenylalanine and the produced monomer $\mathbf{I}$. As described in experimental part, after evaporation of 1,4-dioxane and washing of the residual aqueous solution by ethyl acetate, the aqueous solution was acidified by hydrochloric acid. White precipitates were formed, but IR spectroscopic analysis suggested that the precipitates were not monomer I but probably the mixture of monomer $\mathbf{I}$ and its sodium salt. Monomer I was extracted by ethyl acetate, which was then purified by recrystallization from water.

The syntheses of $p$-toluenesulfonic acid salts of bis (amino acid)-1,4-butane diesters (monomers IIa-IId) were conducted according to Scheme 2 . Direct condensa- tion of $\alpha$-amino acid with alcohol in the presence of $p$ toluenesulfonic acid in refluxing benzene or carbon tetrachloride has been used in peptide chemistry. Huang et $a l .^{8}$ suggested that this method could be used for preparation of $\alpha, \omega$-diamino diester from L-phenylalanine and 1,2-ethanediol. It was pointed out that the reaction became homogeneous and reaction rate increased by addition of nitrobenzene as a cosolvent. ${ }^{13}$ In our present work, the reactions between L-amino acids (phenylalanine, leucine, valine, and alanine) and 1,4butanediol gave optically active products (monomers II) as $p$-toluenesulfonic acid salts which could be purified by recrystallization from water. However, synthesis of the diester monomer from glycine was unsuccessful. Only a very viscous syrup was obtained, and the product did not show IR absorption bands characteristic of ester groups.

\section{Synthesis of Polymers}

The outline of polymer synthesis is shown in Scheme 3. Polyesteramides IIIa-IIId were synthesized from monomer I and monomers IIa-IId in DMF using 1-ethyl-3-(3-dimethylaminopropyl)carbodiimide hydrochloride (EDC $\cdot \mathrm{HCl}$ ) as a coupling agent. There may be several synthetic routes to polyesteramides containing dipeptide groups. For example, polycondensation of dicarboxylic acid and diamines, either of which have dipeptide groups, would give dipeptide-containing polymers. The disadvantage of this method is the difficulty of the synthesis of dipeptide-containing monomers. Many reactions for protection and activation of amino- or carboxyl groups would be required. In the present work, we employed the condensation of an acid component (monomer I) and an amine component (monomer II) each of which has an amino acid residue. Easy synthesis of these monomers and the possibility of wide selection of amino acids to form dipeptide groups are of great advantage of this method. Furthermore, advantage of this 


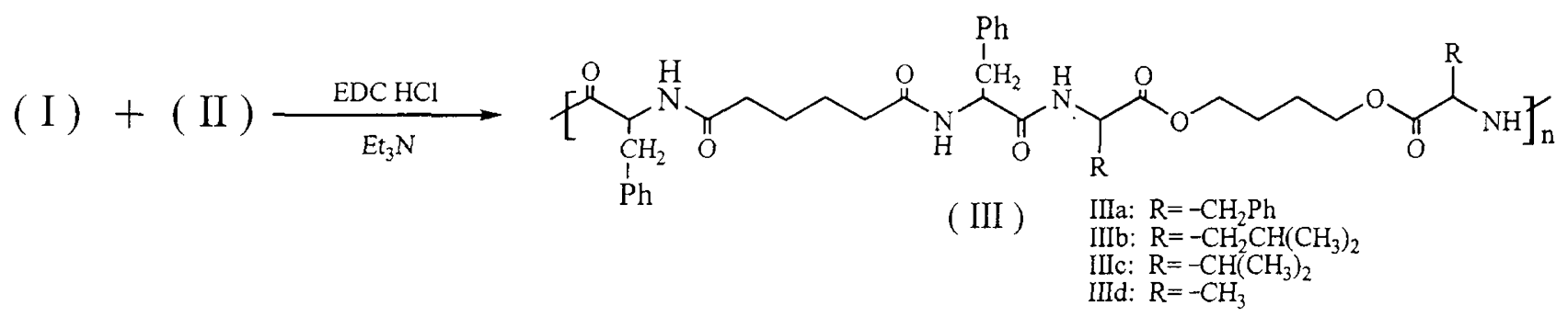

Scheme 3.

Table I. Characteristics of the polyesteramides III

\begin{tabular}{cccccc}
\hline Polymer & $-\mathrm{R}^{\mathrm{a}}$ & Yield $/ \%$ & $M_{\mathrm{n}}{ }^{\mathrm{b}}$ & $M_{\mathrm{n}} / M_{\mathrm{w}}{ }^{\mathrm{b}}$ & {$[\alpha]_{\mathrm{D}}{ }^{\mathrm{c}}$} \\
\hline IIIa & $-\mathrm{CH}_{2} \mathrm{Ph}$ & 90 & 7700 & 1.37 & -11.0 \\
IIIb & $-\mathrm{CH}_{2} \mathrm{CH}\left(\mathrm{CH}_{3}\right)_{2}$ & 77 & 5600 & 1.46 & -13.3 \\
IIIc & $-\mathrm{CH}^{2}\left(\mathrm{CH}_{3}\right)_{2}$ & 84 & 6800 & 1.36 & -4.7 \\
IIId & $-\mathrm{CH}_{3}$ & 71 & 7200 & 1.48 & -6.6 \\
\hline
\end{tabular}

${ }^{\mathrm{a}} \mathrm{R}$ in Scheme $3 ;{ }^{\mathrm{b}}$ Measured by GPC; ${ }^{\mathrm{c}}$ In DMAc at $25^{\circ} \mathrm{C}, c=$ $0.5, l=100 \mathrm{~mm}$.

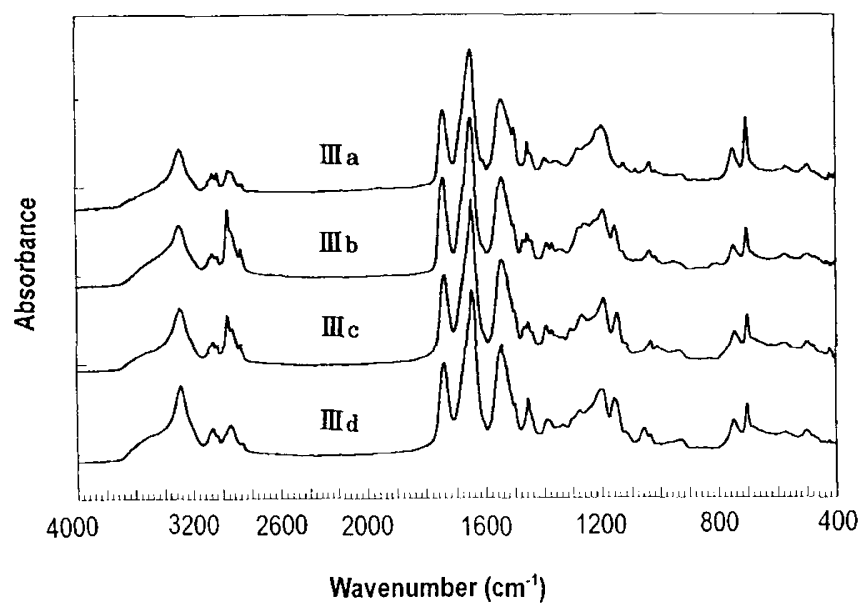

Figure 1. IR spectra of polyesteramides IIIa-IIId.

method is associated with the fact that the technique of amino acid coupling using carbodiimides has been established in peptide chemistry. This provided us with a facile synthetic method of the polyesteramides having peptide groups.

Table I summarizes the characteristics of the polymers obtained after washing with water and ethanol to remove oligomers and unreacted monomers. Although the polyesteramide III a contains the sterically hindered Phe-Phe linkages in the main chain, its yield and number-average molecular weight $\left(M_{n}\right)$ were the highest among the polymers synthesized. This suggested that the polycondensation was controlled by some factors other than steric hindrance. The difference in nucleophilicity of the amino groups in monomers II may affect the reactivity with the monomer $\mathbf{I}$, which would affect the yield and molecular weight of the polymers. The ratio between the two monomers as well as the side reactions such as formation of acylurea from monomer $I$ and the carbodiimide may also affect the yield of the poly-

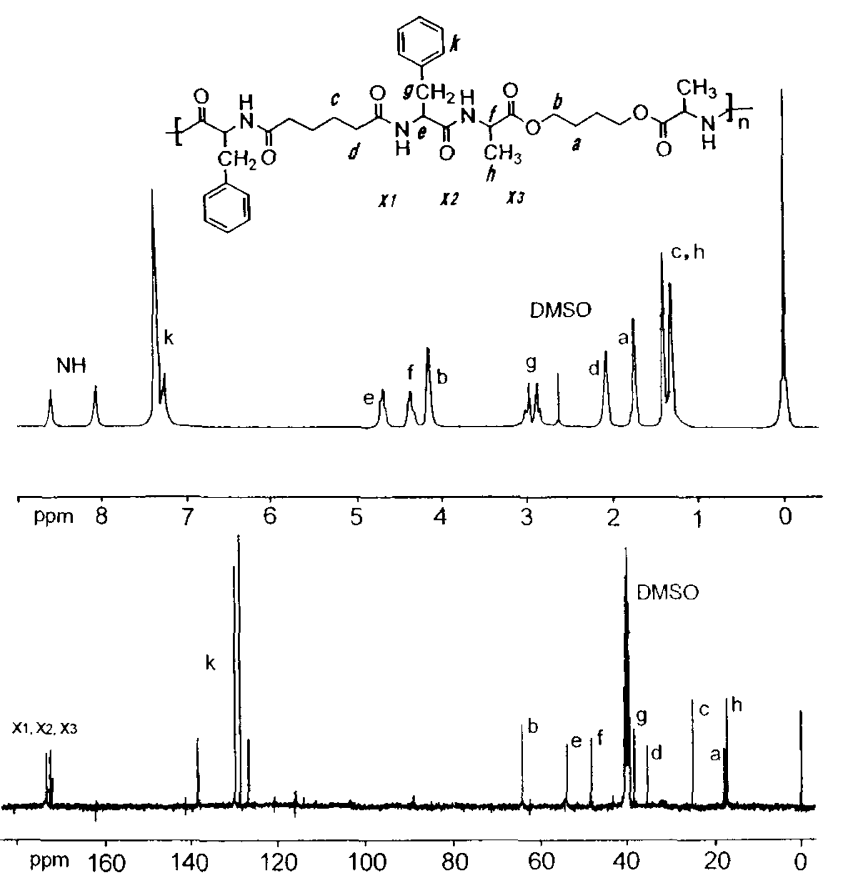

Figure 2. ${ }^{1} \mathrm{H}$ (upper) and ${ }^{13} \mathrm{C}$ NMR (lower) spectra of polyesteramide IIIa.

mers.

Infrared spectra of the polymers (Figure 1) show typical absorption bands due to methylene, methyl, and ester groups at about 2950,2830 , and $1740 \mathrm{~cm}^{-1}$, respectively. Bands at 1645 and $1549 \mathrm{~cm}^{-1}$ were assigned to amide groups. As expected, IIIb and IIIc have the stronger absorption bands of methylene and methyl groups than IIIa and IIId. Note that for all these polymers, a shoulder on the amide II peak $\left(\sim 1540 \mathrm{~cm}^{-1}\right.$, $\mathrm{N}-\mathrm{H}$ bending) is observed, which indicates that there may be some kind of interaction between amide and ester groups. ${ }^{16}$ Typical ${ }^{1} \mathrm{H}$ and ${ }^{13} \mathrm{C}$ NMR spectra are shown in Figure 2. The spectra are consistent with the structure, as the assignments of the peaks are shown in Figure 2 .

The solubility of the polymers is listed in Table II. All the polymers were soluble in hydrogen bond breaking solvents, such as formic acid. They were also soluble in polar aprotic solvents, such as DMSO and DMF, as well as in chloroform, but insoluble in alcohols, ethyl acetate, and acetone.

\section{Biodegradation Studies}

Several reports have appeared on the biodegradation 
Table II. Solubility of polyesteramides ${ }^{\text {a }}$

\begin{tabular}{|c|c|c|c|c|c|c|c|c|c|}
\hline Polymer & $\begin{array}{c}\text { Formic } \\
\text { Acid }\end{array}$ & DMSO & DMF & DMAc & $\mathrm{CHCl}_{3}$ & $\mathrm{MeOH}$ & $\mathrm{EtOH}$ & Acetone & $\begin{array}{c}\text { Ethyl } \\
\text { acetate }\end{array}$ \\
\hline$\overline{\text { III a }}$ & + & + & + & + & + & - & - & - & - \\
\hline IIIb & + & + & + & + & + & - & - & - & - \\
\hline IIIc & + & + & + & + & + & - & - & - & - \\
\hline IIId & + & + & + & + & + & - & - & - & - \\
\hline
\end{tabular}

${ }^{\mathrm{a}}$ Tested at room temperature with about $20 \mathrm{mg}$ of polymer and $0.5 \mathrm{~mL}$ of solvent. $+:$ soluble; $-:$ insoluble.

Table III. TOC for hydrolysis by enzymes ${ }^{a}$

\begin{tabular}{ccccc}
\hline Enzyme & IIIa & IIIb & IIIc & IIId \\
\hline$\alpha-C T$ & 820 & 540 & 1040 & 1440 \\
STC & 470 & 250 & 520 & 1340 \\
STB & 520 & 340 & 500 & 1370 \\
LCC & 350 & 290 & 150 & 1040 \\
\hline
\end{tabular}

${ }^{a}$ Performed in $10 \mathrm{~mL}$ of $0.1 \mathrm{M}$ borate buffer $(\mathrm{pH}=8)$ with $20 \mathrm{mg}$ of the polymers and $1 \mathrm{mg}$ of the enzymes.

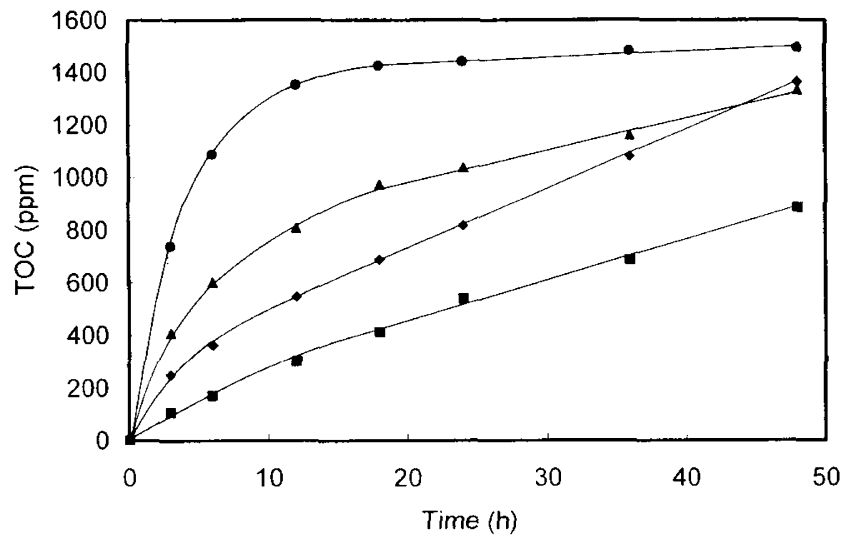

Figure 3. Degradation of polyesteramides $(20 \mathrm{mg})$ by $\alpha$-CT $(1 \mathrm{mg})$ in $0.1 \mathrm{M}$ borate buffer $(\mathrm{pH} 8,10 \mathrm{~mL})$ at $30^{\circ} \mathrm{C}$ : IIIa; IIIb; $\triangle$ : IIIc; : IIId.

of polyesteramides, ${ }^{13,17,18}$ but the synthesis and biodegradation of those having peptide groups have rarely been reported. $\alpha$-Chymotrypsin ( $\alpha$-CT ) is known to hydrolyze peptides containing aromatic amino acids as carboxyl components ( $\mathrm{P}_{1}$ specificity). ${ }^{19,20}$ Therefore, this enzyme was used for biodegradation study of the polyesteramides III which have phenylalanine residue as a carboxyl component in the peptide groups. Figure 3 shows the time course of degradation of the polyesteramides by $\alpha$-CT in $0.1 \mathrm{M}$ borate buffer at $\mathrm{pH} 8$ that is optimum for $\alpha$-CT. Without enzyme, no reaction was detected in $24 \mathrm{~h}$ for all of the polymers. It seemed that degradation rate increased with the increase in hydrophilicity of the amino acid residues as amine components in the peptide groups; polyesteramide IIId with $\mathrm{Phe}-\mathrm{Ala}$ linkages showed the fastest degradation among the 4 polymers followed by IIIc ( $\mathrm{Phe}-\mathrm{Val})$, IIIa ( $\mathrm{Phe}-\mathrm{Phe}$ ), and IIIb (Phe-Leu). It has been reported that the $\mathrm{P}_{1}{ }^{\prime}$ specificity of $\alpha$-CT was in the order Ala $>$ Val $>$ Leu $>$ $\mathrm{Phe}^{21}$ for hydrolysis of peptides. Our result is in agreement with the reported data except that IIIa is more reactive than IIIb. In the case of IIIa, hydrolytic cleavage can occur not only at the peptide linkages, but also at

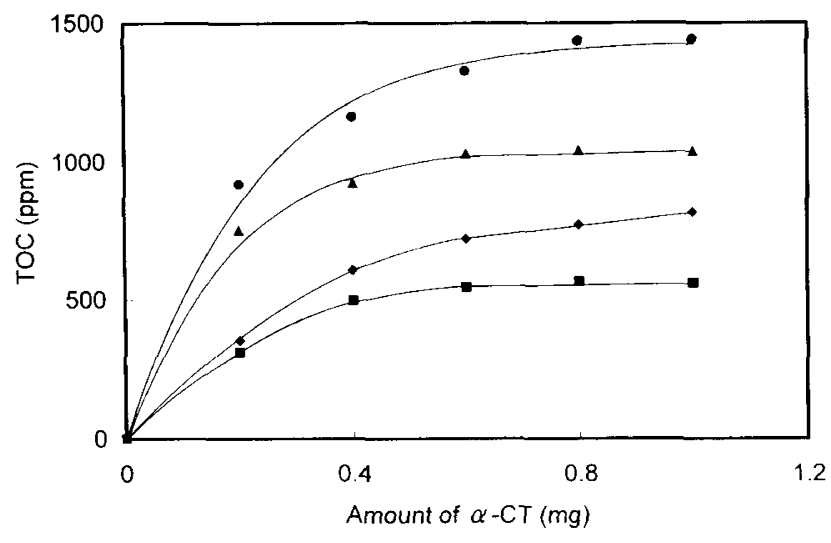

Figure 4. Degradation of polyesteramides $(20 \mathrm{mg})$ using different amounts of $\alpha$-CT in $0.1 \mathrm{M}$ borate buffer $\left(\mathrm{pH} 8,10 \mathrm{~mL}\right.$ ) at $30^{\circ} \mathrm{C}$ ४: IIIa; $\square$ : IIIb; $\triangle$ : IIIc; : IIId.

the ester bonds between phenylalanine and 1,4butanediol unit. This is because $\alpha$-CT exhibits not only peptidase activity but also esterase activity to hydrolyze aromatic amino acid esters. ${ }^{19,20}$

Interestingly, as shown in Figure 4, with an increase in the amount of $\alpha$-CT, the TOC after $24 \mathrm{~h}$ increased first but reached almost constant; TOC values seem to saturate when degradation was carried out with more than $0.6 \mathrm{mg}$ of $\alpha$-CT. This is especially distinct in the case of IIIa and IIIb, where the TOCs reached only $1 / 2$ $-1 / 3$ of the theoretical values for complete hydrolysis. The reason is not clear at present, but it is likely that the surface area of the polymers is a rate determining factor; in this case excess enzyme would not catalyze the reaction, thus giving saturation curves for the plots of TOC $v s$. amount of the enzyme.

Subtilisin Carlsberg (STC) and subtilisin BPN' were also used for degradation of these polymers. The results are summarized in Table III. It is known that substrate specificities of STC and STB for peptide hydrolysis are very similar to that of $\alpha$-CT. Table III shows that the specificities of STC and STB for the polymer degradation are very similar to that of $\alpha$-CT, although degradation by STC or STB was slower than that by $\alpha$-CT. These results suggest that degradation by STC and STB was due to hydrolysis of the peptide bonds. However, since STC and STB exhibit esterase activity, the polymers may be also hydrolyzed at the ester linkages.

Degradation by lipase from Candida cylindracea (LCC) gave the result that IIId was the most reactive (Table III). In general, lipases are effective catalysts for hydrolysis of aliphatic esters. Therefore, in the present case, ester bonds in 1,4-butanediol units may be the primary sites of hydrolysis, so the hydrolysis behavior by the lipase may be different from that by proteases. 
In conclusion, polyesteramides containing peptide linkages were synthesized form natural amino acids, adipoyl chloride, and 1,4-butanediol using EDC $\cdot \mathrm{HCl}$ as a coupling agent. They had medium molecular weights and could be effectively degraded by enzymes in vitro. Introduction of Phe-Ala linkages in polymer chains was the most effective for degradation by enzymes including microbial proteases and lipase. The polymers may be promising materials for agricultural or biomedical applications.

\section{REFERENCES}

1. G. Swift, M. Creamer, X. Wei, and K. Yocom, Macromol. Symp., 130, 379 (1998).

2. M. Mochizuki and M. Hirami, Polym. Adv. Tech., 8, 203 (1997).

3. M. Vert, M. S. Li, G. Spenlehauer, and P. Guerin, J. Mater. Sci.-J. Mater. Med., 3, 432 (1992).

4. S. Bera and Z. Jedlinski, J. Polym. Sci., Part A: Polym. Chem., 31, 731 (1993).

5. I. Arvanitoyannis, A. Nakayama, N. Kawasaki, and N. Yamamoto, Makromol. Chem., 222., 111 (1994).

6. T. Kiyotsukuri, D. Miura, N. Tsutsumi, and W. Sakai, Polymer, 37, 327 (1996).

7. A. J. Domb, Biomaterials, 111, 686 (1990).
8. S. J. Huang, D. A. Bansleben, and J. R. Knox, J. Appl. Polym. Sci., 23, 429 (1979).

9. K. E. Gonsalves and X. Chen, J. Polym. Sci., Part A: Polym. Chem., 31, 701 (1993).

10. M. Bermudze, J. Puiggali, and S. Munoz-Guerra, Macromolecules, 27, 6325 (1994).

11. Y. Saotome, T. Miyazawa, and T. Endo, Chem. Lett., 21 (1991).

12. Y. Saotome, T. Miyazawa, and T. Endo, Chem. Lett., 153 (1991).

13. N. Arabuli, G. Tsitlanadze, L. Edilashvili, D. Kharadze, T. Goguadze, V. Beridze, Z. Gomurashvili, and R. Katsarava, Macromol. Chem. Phys., 195, 2279 (1994).

14. N. Paredes, A. Rodriguez-Galan, and J. Puiggali, J. Polym. Sci., Part A: Polym. Chem., 36, 1271 (1998).

15. B. Deschrevel, J-C. Viincent, and M. Thellier, Arch. Biochem. Biophys., 304, 45 (1993).

16. B. Kaczmarczyk and D. Sek, Polymer, 36, 5019 (1995).

17. R. Katsarava, V. Beridze, N. Arabuli, D. Kharadze, C. C. Chu, and C. Y. Won, J. Polym. Sci, Part A: Polym. Chem., 37, 391 (1999).

18. M. Nagata, Macromol. Chem. Phys., 200, 2059 (1999).

19. M. Y. Gololobov, T. L. Voyushina, V. M. Stepanov, and P. Adlercreutz, FEBS Lett. 307, 309 (1992).

20. A. Fersht, "Enzyme Structure and Mechanism", W. H. Freeman and Co., New York, N.Y., 1977, p 18.

21. V. Schellenberger, C. W. Turck, L. Hedstrom, and W. J. Rutter, Biochemistry, 32, 4349 (1993) 